Cahiers $d u$ MONDE RUSSE

\section{Cahiers du monde russe}

Russie - Empire russe - Union soviétique et États indépendants

42/2-4 | 2001

La police politique en Union soviétique, 1918-1953

\title{
Stalin i organy gosudarstvennoj bezopasnosti v poslevoennyj period.
}

\section{Oleg HLEVNJUK}

\section{(Q) OpenEdition \\ Journals}

Édition électronique

URL : https://journals.openedition.org/monderusse/8466

DOI : $10.4000 /$ monderusse. 8466

ISSN : $1777-5388$

Éditeur

Éditions de l'EHESS

Édition imprimée

Date de publication : 1 avril 2001

Pagination : 535-548

ISBN : 2-7132-1398-3

ISSN : $1252-6576$

Référence électronique

Oleg HLEVNJUK, «Stalin i organy gosudarstvennoj bezopasnosti v poslevoennyj period. », Cahiers du monde russe [En ligne], 42/2-4 | 2001, mis en ligne le 01 janvier 2007, consulté le 03 septembre 2022. URL : http://journals.openedition.org/monderusse/8466; DOI : https://doi.org/10.4000/monderusse. 8466 
chercher : repérer : avancer

Cet article est disponible en ligne à l'adresse :

http://www.cairn.info/article.php?ID REVUE=CMR\&ID NUMPUBLIE=CMR 422\&ID ARTICLE=CMR 4220535

\title{
Stalin i organy gosudarstvennoj bezopasnosti v poslevoennyj period
}

\author{
par Oleg HLEVNJUK
}

\section{Editions de l'EHESS | Cahiers du monde russe}

\author{
2001/2-3-4 - Vol 42 \\ ISSN 1252-6576 | ISBN 2713213983 | pages 535 à 548
}

Pour citer cet article :

-HLEVNJUK O., Stalin i organy gosudarstvennoj bezopasnosti v poslevoennyj period, Cahiers du monde russe 2001/ 23-4, Vol 42, p. 535-548.

Distribution électronique Cairn pour les Editions de l'EHESS.

(C) Editions de l'EHESS. Tous droits réservés pour tous pays.

La reproduction ou représentation de cet article, notamment par photocopie, n'est autorisée que dans les limites des conditions générales d'utilisation du site ou, le cas échéant, des conditions générales de la licence souscrite par votre établissement. Toute autre reproduction ou représentation, en tout ou partie, sous quelque forme et de quelque manière que ce soit, est interdite sauf accord préalable et écrit de l'éditeur, en dehors des cas prévus par la législation en vigueur en France. Il est précisé que son stockage dans une base de données est également interdit. 


\section{ОЛЕГ ХЛЕВНЮК}

\section{СТАЛИН И ОРГАНЫ ГОСУДАРСТВЕННОЙ БЕЗОПАСНОСТИ В ПОСЛЕВОЕННЫЙ ПЕРИОД}

Несмотря на предположения ряда историков об ослаблении власти Сталина в отдельные периоды его правления, особенно в последние годы жизни, пока с уверенностью можно зафиксировать лишь один факт: мы не знаем ни одного случая за двадцать лет правления Сталина в качестве диктатора, когда его власть подвергалась бы действительно серьезной угрозе. Лишь смерть Сталина вызвала смутные спекуляции по поводу возможности заговора, которые выглядели бы более убедительно, если бы Сталин действительно не был стар и болен.

В любом случае, даже если смерть Сталина была ускорена какими-то действиями его соратников, факт существования двадцатилетней единоличной диктатуры в огромной стране требует изучения и осмысления, чему и посвящена значительная литература. По понятным причинам одним из ключевых объектов в исследованиях сталинской диктатуры являются так называемые «органы государственной безопасности», составлявшие вместе с партией главную опору системы. Многочисленные и взаимосвязанные функции этих двух структур условно можно разделить на две группы. Первая - репрессивное обеспечение социально-экономического курса, проводимого сталинским руководством (форсированной индустриализации, экспроприации крестьянской собственности при помощи коллективизации и т.д.), и подавление социального недовольства. Вторая - обеспечение собственно диктаторских полномочий Сталина. Если в первом случае речь шла о терроре против населения страны в целом, то во втором - преимущественно о контроле и репрессиях против партийно-государственного аппарата, включая его верхушку.

Практика активного использования чекистских органов во внутрипартийной борьбе берет свое начало с 20-х годов, с периода острых столкновений различных фракций в высшем руководстве партии. Победа Сталина и его сторонников в этой борьбе в значительной мере была предопределена тем, что они контролировали ОГПУ. Являясь формально подразделением 
Совнаркома, на практике ОГПУ напрямую подчинялось руководству партии, прежде всего Сталину. Со временем это подчинение становилось все более безусловным. Именно при помощи органов ОГПУ-НКВД Сталин произвел массовую чистку в партийно-государственном аппарате, привел к власти новое поколение руководителей, свел до минимума значение и политическое влияние других лидеров партии, заменив олигархическое «коллективное» правление Политбюро своей личной диктатурой.

Сложившиеся в 30-е годы методы подавления соратников Сталин использовал и в послевоенный период. Самым крайним среди этих методов было физическое уничтожение высших советских руководителей. Порядок фабрикации дел против членов Политбюро был таким, что само Политбюро, а тем более ЦК ВКП(б), которому Политбюро формально подчинялось, не могли ни в какой мере контролировать этот процесс. Руководители МГБ (как показывают, например, документы так называемого «ленинградского дела») выполняли прямые поручения Сталина и предоставляли только ему соответствующие материалы, - как правило, протоколы допросов, сфальсифицированные в заданном Сталиным направлении ${ }^{1}$. Решение о рассылке (или не рассылке) этих документов другим членам советского руководства принимал также Сталин.

Широко, как в довоенные, так и в послевоенные годы, Сталин применял в качестве метода подавления своих соратников аресты их ближайших родственников или сотрудников. Общеизвестна, например, драма, разыгрывавшаяся в семье второго человека в государстве - В. М. Молотова. Его жена П. С. Жемчужина накануне войны обвинялась в непреднамеренных связях с «врагами», а после войны, в начале 1949 г., была арестована. Как показывают новые документы, попытки Молотова сопротивляться (первоначально Молотов воздержался при голосовании в Политбюро предложения об исключении Жемчужиной из партии) были жестко подавлены Сталиным. Молотов вынужден был написать унизительное заявление с признанием своей «политической ошибки» ${ }^{2}$. Причем, пример Молотова был нетипичным. Другие члены Политбюро безропотно принимали подобные репрессии и старательно демонстрировали преданность вождю.

Сама система организации работы и даже отдыха советских руководителей различных уровней вполне легально позволяла органам государственной безопасности следить за каждым их шагом. В введении госбезопасности находилась не только постоянная охрана советских чиновников, но осуществление связи, доставка и оформление корреспонденций (как правило, пересылавшихся шифром), специальная телефонная связь (так называемая «ВЧ»), дачи под Москвой и на юге, снабжение и т.д. Кроме того,

1. Большое количество таких протоколов допросов сохранилось в личном архиве Сталина.

2. Российский государственный архив социально-политической истории (РГАСПИ), ф. 558, оп. 11, д. 77, л. 152; А. А. Данилов, «Сталинское Политбюро в послевоенные годы», в: Политические партии России. Страницы истории, М., 2000, с. 211. 
использовались специальные формы контроля. Например, по свидетельству высокопоставленного чекиста Судоплатова, в 1950 г. Сталин приказал установить подслушивающую аппаратуру у Молотова и Микояна 3 .

Опираясь на органы госбезопасности, Сталин, однако, не превращался в их заложника. Он всегда относился к чекистам с особым подозрением не только в силу своего характера, но и потому, что хорошо знал суть их работы. Поручая госбезопасности самые грязные дела, Сталин не питал иллюзий относительно возможностей и нравственного потенциала того, обоюдоострого «меча революции». Основным сталинским методом тщательного контроля над карательными органами были регулярные реорганизации и кадровые чистки. Проводились они, как правило, на основе манипулирования двумя самыми могущественными структурами системы партией и госбезопасностью. Репрессии против партийных функционеров осуществлялись руками чекистов, но в определенный момент карательные органы ставились «под контроль партии», подвергались чистке и «укреплялись» сверху донизу кадрами из партаппарата. В разной степени этот механизм использовался на протяжении всего периода сталинского правления при замене Г. Г. Ягоды на Н. И. Ежова в 1936 г., Н. И. Ежова на Л. П. Берия в 1939 г., В. С. Абакумова на С. Д. Игнатьева в 1951 г.

В какой-то степени исключением из этого правила было назначение в мае 1946 г. министром госбезопасности Абакумова. Но и в этом случае Сталин использовал принцип противопоставления двух конкурирующих спецслужб - МГБ, во главе которого стоял выдвиженец Берия В. Н. Меркулов, и военной контрразведки «Смерш», которую возглавлял Абакумов. Назначение Абакумова состоялось по прямому настоянию Сталина и, как уже неоднократно отмечалось в литературе, преследовало цель не только произвести очередную кадровую перетряску, но ослабить позиции Берия и Маленкова 4 . В этой связи обращает на себя внимание тот факт, что назначение Абакумова произошло после того, как под его руководством органами «Смерш» была проведена фабрикация так называемого «дела авиаторов», в результате чего Маленков, курировавший авиационную промышленность, был лишен в мае 1946 г. должности секретаря ЦК ВКП(б) ${ }^{5}$.

В течение некоторого времени, пока происходила передача дел от Меркулова к Абакумову, аппарат МГБ находился в неопределенном состоянии. Однако, несмотря на многочисленные обвинения в адрес Меркулова, репрессии на этот раз в целом обошли МГБ стороной. Сам Меркулов сохранил расположение Сталина и получил новую высокую должность.

Как и другие руководители советских спецслужб, Абакумов работал под непосредственным контролем Сталина, хотя многие текущие вопросы он согласовывал с А. А. Кузнецовым, который курировал МГБ в качестве

3. П. А. Судоплатов, Разведка и Кремль, М., 1996. с. 383.

4. A. Knight, Beria. Stalin's first lieutenant, Princeton University Press, 1993, pp. 140-142.

5. РГАСПИ, ф. 17, оп. 163, д. 1482, л. 56. 
секретаря ЦК ВКП(б). Несомненно, что со Сталиным Абакумов согласовывал все принципиальные проблемы и получал от него принципиальные указания, а на долю Кузнецова приходились рутинные вопросы, относительно второстепенного характера. Однако четкого разделения сфер взаимодействия Абакумова и Сталина, с одной стороны, и Абакумова и Кузнецова - с другой, не существовало. Есть основания считать, что Сталин внимательно следил за этим разделением и старался поставить под свой контроль максимально широкий круг вопросов, касавшихся МГБ. Характерный конфликт произошел в начале 1948 г. В связи с организацией по инициативе Сталина судов чести - новой формы кадровых чисток в партийно-государственном аппарате 6 - Абакумов решил продемонстрировать пример бдительности и провел в МГБ суд чести над двумя сотрудниками. Сталин усмотрел в этом решении непозволительную самостоятельность. От Абакумова потребовали объяснений, и он сослался на то, что согласовал вопрос с Кузнецовым. В принципе, по меркам аппаратной работы вопрос действительно не был существенным, а поэтому поведение Абакумова и Кузнецова не выходило за рамки дозволенного. Однако Сталин явно решил воспользоваться этим случаем, чтобы еще раз подчеркнуть свои исключительные права на контроль за МГБ. 15 марта 1948 г. Политбюро приняло специальное решение, в котором Абакумов получил взыскание за то, что организовал суд чести «без ведома и согласия Политбюро», а Кузнецов за то, что дал «единоличное согласие на организацию суда» 7 .

Подобные демарши свидетельствовали о том, что рано или поздно Сталин начинал подозревать руководителей госбезопасности в излишней самостоятельности и начинал готовить очередную кадровую перетряску. Такая перетряска, как показывали примеры Берия и Меркулова, не обязательно заканчивалась репрессиями. Однако в случае с Абакумовым обычная «плановая» реорганизация руководства органов МГБ накладывалась на существенные перемены в «большой политике», что в значительной мере предопределило судьбу Абакумова и его помощников.

По роду своей деятельности Абакумов, как уже говорилось, помимо Сталина, поддерживал контакты с Кузнецовым, а также должен был считаться с влиянием заместителя Сталина по партии А. А. Жданова, т.е., условно говоря, «группы ленинградцев». Что касается другой, противостоящей «ленинградцам» группы - Берия и Маленкова, то мы имеем многочисленные свидетельства о том, что с ними у Абакумова складывались (по крайней мере, первоначально) прохладные отношения. Причины этого очевидны - именно руками Абакумова Сталин провел в 1946 г. атаки против Маленкова (в связи с «делом авиаторов») и Берия (в связи со смещением Меркулова). Осторожный Берия опасался Абакумова и, по свидетельствам Меркулова и Судоплатова, старался не конфликтовать с ним и наладить

6. Подробнее о судах чести см.: Источник, 6, 1994, сс. 68-81 (публикация Н. Сидорова).

7. РГАСПИ, ф. 17, оп. 163, д. 1509, л. 222. 
хорошие отношения ${ }^{8}$. Ситуация изменилась в связи со смертью Жданова и фабрикацией в 1949 г. «ленинградского дела». Абакумов, получивший от Сталина приказ о подготовке этого дела и доведении его до расстрела Кузнецова, Вознесенского и других арестованных, действовал теперь в команде Берия-Маленкова против «ленинградцев».

В значительной мере положение, в которое попал Абакумов, было схожим с положением, в котором оказался в 1936 г. Ягода, готовивший по приказу Сталина процесс против так называемого «объединенного троцкистско-зиновьевского центра». Связанные прошлыми отношениями с подсудимыми, и Ягода, и Абакумов, судя по многим фактам, первоначально не проявляли большой активности в фабрикации дел, ограничивая их достаточно узкими рамками. В частности, Абакумов не сразу согласился вести следствие по пути выявления «шпионажа» «ленинградцев» в пользу иностранных государств 9 . Что касается Сталина, то он и в 1936, и в 1949 г. вел себя примерно одинаково. Столкнувшись с легким противодействием (или, точнее, недостаточным пониманием), Сталин заставил Ягоду и Абакумова вести «расследование» в том направлении, в каком считал необходимым, а для контроля приставил к ним в первом случае Ежова, а во втором - Маленкова. Одинаковой оказался также судьба Ягоды и Абакумова после того, как они провели процессы и выполнили свою роль.

Пока шла фабрикация «ленинградского дела», за которой внимательно следил Сталин, у Абакумова, видимо, укрепились иллюзии по поводу прочности своего положения. Прежние инциденты, касавшиеся Берия и Маленкова, остались в прошлом. Сталин в целом был доволен ходом подготовки процесса над «ленинградцами». По некоторым данным, в окружении Абакумова в этот период даже распространялись слухи о возможности его назначения в Политбюро ${ }^{10}$

29-30 сентября 1950 г. состоялся судебный процесс по делу Кузнецова, Вознесенского и других «ленинградцев». 1 октября они были расстреляны. Примерно через месяц, 3 декабря, было принято постановление Политбюро, свидетельствовавшее о том, что Сталин считал необходимым провести очередную перетряску в органах госбезопасности. Количество заместителей министра увеличивалось до семи, а на ключевой пост заместителя министра по кадрам вместо М. Г. Свинелупова выдвигался заведующий

8. Неизвестная Россия $Х Х$ век, кн. 3, М., 1993, с. 73; П. А. Судоплатов, указ. соч., сс. 285-286.

9. К. А. Столяров, Палачи и жертвы, М., 1998, с. 52. Стремление скрыть связь группы Кузнецова с иностранными разведками выдвигалось как один из важнейших пунктов обвинительного заключения против Абакумова. Сталин, как свидетельствовала его правка этого документа, придавал этим обвинениям особое значение (см. Р. Г. Пихоя, Советский Союз: История власти, 1945-1991, M., 1998, c. 92).

10. Государственный архив Российской Федерации (ГАРФ), ф. Р-8131, оп. 32, д. 3289, лл. 48-57. Кстати, есть смутные свидетельства о том, что место в Политбюро Сталин периодически обещал и Ягоде. 
административным отделом ЦК ВКП(б) В. Е. Макаров. В Москву в качестве начальника Главного управления охраны МГБ СССР на железнодорожном и водном транспорте переводился близкий к Берия С. А. Гоглидзе, ранее прозябавший в должности начальника управления МГБ Хабаровского края ${ }^{11}$.

Принципиальное значение имеют отметки в подлинном протоколе заседаний Политбюро, позволяющие выяснить некоторые обстоятельства подготовки постановления. Во-первых, из них следует, что проект документа был подготовлен уже в августе 1950 г., что с большой долей вероятности позволяет предположить, что Сталин отложил решение вопроса до завершения процесса над «ленинградцами». Во-вторых, в подлинном проколе на первой странице постановления сохранилась резолюция Поскребышева: «Заготовить. 1 экз[емпляр] послать т. Маленкову и окончательно оформить после его звонка» ${ }^{12}$, что свидетельствует о прямой причастности Маленкова к подготовке реорганизации МГБ.

Суть постановления заключалась в том, что Абакумов окружался новыми людьми и лишился некоторых из своих соратников. Сталин в данном случае использовал традиционную схему — выдвижение в органы госбезопасности на принципиальную должность человека из партийного аппарата (В. Е. Макарова). Скорее всего, Макаров, получивший поручение заниматься кадрами, должен был стать проводником новой реорганизации, подготовить необходимые материалы для ее проведения. Постановление от 3 декабря, таким образом, может рассматриваться как свидетельство намерений Сталина провести очередную смену руководства МГБ. Однако, что касается судьбы самого Абакумова, нельзя утверждать, что Сталин уже тогда предрешил его уничтожение. События вполне могли развиваться по сценарию 1946 г., когда смещенный Меркулов, пережив ужас сталинской критики, сохранил не только жизнь, но и положение в номенклатурной системе. Однако в судьбе Абакумова роковую роль сыграл донос одного из его подчиненных — подполковника М. Д. Рюмина.

В доносе, который Рюмин подал на имя Сталина, Абакумов обвинялся в различных преступлениях, главным образом в том, что тормозил расследование дел о террористических группах, готовивших покушения против вождей страны, — «группы врачей», «молодежной еврейской организации». Обстоятельства появления заявления Рюмина почти неизвестны. Рюмин мог подать заявление как по собственной инициативе, так и по подсказке сверху. Сам Рюмин, арестованный после смерти Сталина, на допросе показывал, что написать донос его заставила боязнь за собственную судьбу — в мае управление кадров МГБ начало проверку сведений о ближайших родственниках Рюмина и выявило, что он скрыл ряд важных компрометирующих фактов ${ }^{13}$. Это заявление похоже на правду. Напомним, что в

11. РГАСПИ, ф. 17 , оп. 163 , д. 1543, лл. 49-52.

12. РГАСПИ, ф. 17, оп. 163, д. 1543, лл. 49, 50.

13. К. А. Столяров, указ. соч., с. 42. 
декабре 1950 г. в МГБ были назначены новые руководящие работники, в частности, заместитель министра по кадрам Макаров, что предполагало проверку аппарата министерства. Донос Рюмина вполне мог быть следствием кадровой перетряски, затеянной Сталиным. Более того, вероятно, Сталин рассчитывал получить такого рода сигналы, а поэтому бумага Рюмина сразу же попала в центр внимания.

Пока неизвестны документы, позволяющие точно выяснить, каким образом заявлению Рюмина был дан ход. Очевидно, что это было сделано по прямому указанию Сталина, даже если заявление попало к Сталину не прямо от Рюмина, а через кого-то из членов Политбюро (например, через Берия или Маленкова). Вполне возможно, что какой-то первоначальный донос Рюмина был с чьей-то помощью (например, того же Маленкова) переработан и заострен в указанном Сталиным направлении. Письмо Рюмина, судя по материалам Президентского архива, которыми пользовался Р. Г. Пихоя ${ }^{14}$, было датировано 2 июля, а уже 4 июля 1951 г. Политбюро приняло постановление: «Поручить Комиссии в составе т.т. Маленкова (председатель), Берия, Шкирятова и Игнатьева проверить факты, изложенные в заявлении т. Рюмина, и доложить о результатах Политбюро ЦК ВКП(б). Срок работы Комиссии 3-4 дня» ${ }^{15}$. Способ оформления этого постановления дает основания для некоторых наблюдений и предположений.

Во-первых, в подлинном протоколе заседаний Политбюро проект постановления был записан Маленковым, а также отсутствовали отметки о голосовании. Обычно это происходило в тех случаях, когда вопрос решался на встречах Сталина с его ближайшими соратниками. Поскольку 4 июля 1951 г. в кремлевском кабинете Сталина никакие заседания не зафиксированы, можно предположить, что вопрос решался на сталинской даче. Вовторых, в проекте постановления, записанном Маленковым, не упоминался заведующий отделом партийных, профсоюзных и комсомольских органов ЦК ВКП(б) С. Д. Игнатьев. Его фамилия была внесена секретарем в машинописный текст постановления с припиской: «Исправление внесено по указанию т. Маленкова 5 VII». Вероятно, решение по поводу Игнатьева было принято в ночь на 5 июля на заседании в кабинете Сталина, где с 0 часов 30 минут присутствовали Молотов, Булганин, Берия, Маленков, с 1 часа к ним присоединился Абакумов, а с 1 часа 40 минут - Рюмин ${ }^{16}$. Включение Игнатьева в состав комиссии в последний момент могло свидетельствовать о том, что либо Сталин до последнего момента не определился с судьбой Абакумова, либо оттягивал выбор его приемника, либо просто из осторожности не хотел раньше времени раскрывать свои намерения.

В отведенные несколько дней комиссия Политбюро, опираясь на заявление Рюмина, провела допросы как самого Абакумова, так и его заместите-

14. Р. Г. Пихоя, указ. соч., с. 82.

15. РГАСПИ, ф. 17, оп. 163, д. 1590, л. 135.

16. Исторический архив, 1, 1997, с. 21. 
лей. В результате донос Рюмина был признан объективным. 11 июля 1951 г. Политбюро приняло решение «О неблагополучном положении в Министерстве государственной безопасности СССР». Абакумова обвинили в развале ряда важнейших дел, в нарушениях законности, неискренности и нежелании признавать свои преступления. В результате Политбюро постановило снять Абакумова с должности министра государственной безопасности и передать его дело в суд. Помимо Абакумова, были сняты с занимаемых постов и исключены из партии или получили выговоры еще несколько высокопоставленных работников МГБ. Политбюро обязало МГБ возобновить следствие по делам «группы врачей» и «еврейской антисоветской молодежной организации». Игнатьев был назначен представителем ЦК ВКП(б) в МГБ, что в значительной мере предопределяло его последующее назначение новым министром госбезопасности. 13 июля это постановление было изложено в закрытом письме ЦК ВКП(б), предназначенном для рассылки руководителям местных партийных организаций (от республик до областей) и подразделений МГБ ${ }^{17}$. В письме (помимо постановления от 11 июля) содержался призыв к партийным руководителям «всемерно усилить свое внимание и помощь органам МГБ в их сложной и ответственной работе». Такие призывы, наряду с фактом назначения на пост министра (которое официально Политбюро утвердило 9 августа 1951 г.) заведующего отделом партийных, профсоюзных и комсомольских органов ЦК ВКП(б), означали, что Сталин еще раз использовал уже опробованный им метод чистки органов госбезопасности с опорой на партийные структуры.

Игнатьев, работавший на рядовых должностях в органах милиции и ВЧК лишь в начале своей карьеры, в качестве министра госбезопасности был нужен Сталину как дисциплинированный исполнитель, к тому же не обремененный связями и групповыми интересами в чекистском ведомстве. Вскоре на ответственные должности в МГБ были назначены другие партийные работники, и одновременно большая группа кадровых чекистов арестована.

Через некоторое время после смещения Абакумова, по инициативе Сталина было организовано так называемое «мингрельское дело». По общему мнению историков, занимавшихся этим «делом», оно в значительной мере было направлено против Берия, сторонники которого в Грузии попали под удар репрессий. Однако в связи с проблемой данной статьи важнее отметить другое обстоятельство: события в Грузии еще раз продемонстрировали те же методы политического манипулирования партией и органами государственной безопасности, к которым прибегал Сталин на общесоюзном уровне, что подтверждает наличие определенной тенденции в сталинской политике в этот период.

17. Постановление от 11 июля проходило под грифом «особая папка» и до сих пор не выдается исследователям, хотя закрытое письмо, полностью содержавшее текст этого постановления, опубликовано: Свободная мысль, 1 , 1996, сc. 90-93. 
Аресты в Грузии проводились под руководством министра госбезопасности Грузии Н. М. Рухадзе, получавшим непосредственные указания от Сталина (у них даже состоялись личные встречи во время отпуска Сталина в сентябре-ноябре 1951 г. ${ }^{18}$ ). Массовые аресты среди высокопоставленных грузинских чиновников привели в конце концов к смещению с поста первого секретаря ЦК компартии Грузии К. Н. Чарквиани и назначению на эту должность его оппонента А. И. Мгеладзе. Рухадзе, между тем, опираясь на поддержку Сталина, дальше разворачивал чистки в республике и вскоре вступил в конфликт с Мгеладзе. Явно переоценив свои силы (точнее, неверно оценив намерения Сталина), Рухадзе начал собирать компрометирующие материалы, выбивая из арестованных показания против Мгеладзе. Сфабрикованные протоколы допросов он послал Сталину.

Реакция Сталина была неожиданной для Рухадзе, но вполне вписывалась в контекст общей линии «укрепления партийного руководства органами МГБ», которая проводилась в этот период. Получив справку Рухадзе, Сталин подготовил ответ ${ }^{19}$, адресованный, однако, не Рухадзе, а Мгеладзе и членам бюро ЦК компартии Грузии. В письме говорилось:

«ЦК ВКП(б) считает, что т. Рухадзе стал на неправильный и непартийный путь, привлекая арестованных в качестве свидетелей против партийных руководителей Грузии [...] Кроме того, следует отметить, что т. Рухадзе не имеет права обходить ЦК КП(б) Грузии и правительство Грузии, без ведома которых он послал в ЦК ВКП(б) материалы против них, поскольку Министерство госбезопасности Грузии, как союзно-республиканское министерство, подчинено не только центру, но и правительству Грузии и ЦК КП(б) Грузиии.»

Выполняя поручение Сталина, в Тбилиси приняли решение о снятии Рухадзе с поста министра госбезопасности. 9 июня 1952 г. это решение было утверждено Политбюро в Москве 20 . Однако Сталин еще некоторое время держал ситуацию в подвешенном состоянии, не давая согласие на арест Рухадзе. 25 июня 1952 г. Сталин телеграфировал руководителям Грузии, которым не терпелось окончательно расправиться со своим врагом: «Вопрос об аресте Рухадзе считаем преждевременным. Советуем довести сдачу-приемку дел [по Министерству госбезопасности Грузии - О. Х.] до конца, после чего направить Рухадзе в Москву, где будет решен вопрос о судьбе Рухадзе» 21 . Вскоре Рухадзе был действительно вызван в Москву и там арестован 22 .

18. К. А. Столяров, указ. соч., сс. 162-168.

19. В архиве Сталина сохранился текст этого документа с правкой Сталина. Судя по стилю, письмо было продиктовано Сталиным (РГАСПИ, ф. 558, оп. 11, д. 135, л. 89).

20. РГАСПИ, ф. 17, оп. 163, д. 1622, л. 141.

21. РГАСПИ, ф. 558 , оп. 11 , д. 135, л. 88.

22. К. А. Столяров, указ. соч., сс. 192-197. 
Существует точка зрения, что в последний период жизни Сталин терял контроль над органами МГБ, признаком чего считается, в частности, смещение в апреле 1952 г. преданного Сталину Н. С. Власика с должности начальника Главного управления охраны МГБ (структуры, отвечавшей за охрану членов советского руководства и самого Сталина), назначение в центральный аппарат МГБ людей Берия (в частности, С. А. Гоглидзе $)^{23}$. В связи с ухудшением состояния здоровья, Сталин, судя по многим признакам, действительно ослабил контроль за деятельностью ряда звеньев партийногосударственного аппарата, не мог столь же активно, как раньше, вникать в проблемы оперативного управления страной. Однако, судя по многим фактам, это не касалось органов государственной безопасности, которые Сталин не выпускал из-под контроля, несмотря на сокращение своих возможностей.

Проведя снятие Абакумова и назначение Игнатьева (руководящая роль Сталина в этих событиях не вызывает сомнений), Сталин отбыл в отпуск, где находился более четырех месяцев. Во время сталинских отпусков его помощники составляли описи материалов, поступавших ему на юг (к сожалению, за периоды пребывания Сталина в Москве такие описи пока неизвестны). Судя по описям за 1951 г., Сталин регулярно и в значительных количествах получал от Игнатьева различные документы и донесения. Всего более чем за четыре месяца (с 11 августа по 21 декабря 1951 г.) Сталин получил от МГБ более 160 различных документов (записки, информационные сообщения), не считая постановлений Политбюро и Совмина, касавшихся МГБ, и разного рода шифровок, содержание и авторство которых в описях не фиксировалось ${ }^{24}$. Сравнение с аналогичными описями за 1945 г. показывает сокращение количества материалов, поступавших от МГБ Сталину на юг. За вдвое более короткий срок (с начала октября до середины декабря 1945 г.) Сталин, судя по описи, получил 215 материалов 25 . Однако это уменьшение произошло в основном за счет неполной пересылки (судя по их номерам) разного рода информационных сообщений. Можно предположить, что Сталину во время последнего отпуска высылались только ключевые сообщения, в то время как в 1945 г. — все. Эта практика вполне вписывалась в контекст общего сокращения активности Сталина и соответствующей перестройки потоков делопроизводства.

Находясь в отпуске, как уже говорилось, Сталин продолжал инициировать различные решения, касающиеся деятельности МГБ. В Москве продолжались кадровые перестановки в высших эшелонах министерства (в частности, заместителем министра, по предложению Сталина, был назначен

23. В наиболее крайней форме, как «заговор Берия» эти события трактует А. Авторханов (А. Авторханов, Загадка смерти Сталина: заговор Берия, Frankfurt/Main, Посев, 1986, cc. 164-171).

24. РГАСПИ, ф. 558, оп. 11, д. 117.

25. РГАСПИ, ф. 558, оп. 11, д. 100. 
Рюмин $\left.{ }^{26}\right)$, в Грузии под непосредственным руководством Сталина разворачивалось «мингрельское дело». Кадровые перетряски в органах госбезопасности (как свидетельствует пример Рухадзе, проходившие под руководством Сталина) продолжались и в 1952 г. Смещение Власика, пострадавшего за многочисленные реальные злоупотребления в Главном управлении охраны, было лишь одним из звеньев этих перестановок.

Несмотря на общее сокращение посещений кремлевского кабинета Сталина (в 1952 г. их было всего 500 по сравнению с 1200 в 1947 г.), Игнатьев 9 раз был у Сталина в Кремле в 1952 г. и, не исключено, посещал его на даче. Вместе с Игнатьевым и отдельно от него у Сталина в Кремле бывали заместители министра госбезопасности С. А. Гоглидзе и С. И. Огольцов 27. Взаимоотношения Игнатьева с его заместителями, а также Гоглидзе и Огольцова между собой требуют специального изучения. Решение о необходимости иметь двух заместителей министра госбезопасности было принято 26 августа 1951 г. в связи с общей сменой руководства МГБ 28 . Тогда же на эти посты назначены Огольцов, работавший заместителем еще у Абакумова, и Гоглидзе, близкий к Берия. Вряд ли такие назначения на ключевые посты были случайными. Сталин манипулировал руководителями МГБ, создавая систему противовесов и взаимного недоверия между ними. Огольцов и Гоглидзе периодически перемещались из центра на местную работу, а затем возвращались в Москву. О многом свидетельствует судьба обоих после смерти Сталина. Если Гоглидзе при поддержке Берия получил высокий пост в новом Министерстве внутренних дел, то Огольцов был арестован, а Игнатьев, стараниями Берия, подвергался гонениям. Пока, таким образом, неизвестны факты, свидетельствующие о возрастающем контроле Берия (или кого-либо другого) над МГБ и соответствующей утрате возможностей Сталина.

В конце 1952 г., за несколько месяцев до смерти, Сталин инициировал новые перестановки в МГБ. Выражая недовольство недостаточной активностью следствия в фабрикации дел о «сионистском заговоре в МГБ» и группы «врачей-вредителей», Сталин в середине ноября 1952 г. выгнал из МГБ Рюмина, а через две недели, 1 декабря, организовал заседание Президиума ЦК для рассмотрения вопроса о «вредительстве» в лечебном деле и положении в МГБ. Материалы этого заседания (если таковые и имелись) пока не известны ${ }^{29}$. Однако мы располагаем важными свидетельствами двух

26. Характерно, как было оформлено постановление Политбюро о назначении Рюмина заместителем министра и начальником следственной части по особо важным делам МГБ от 19 октября 1951 г. В подлиннике протокола была сделана отметка, что постановление принималось по записке Игнатьева, но само постановление, записанное секретарем, не содержало никаких отметок о голосовании, что свидетельствовало о решении вопроса напрямую между Сталиным и Игнатьевым (РГАСПИ, оп. 163, д. 1602, л. 30).

27. См. Исторический архив, 4, 1998, сс. 9, 54, 79, 134.

28. РГАСПИ, ф. 17, оп. 163, д. 1595, л. 130.

29. А. А. Данилов, указ. соч., с. 217. 
участников заседания - В. А. Малышева и Д. Т. Шепилова. По словам Шепилова, «дело врачей» докладывалось на пленуме ЦК, где выступали руководители МГБ и Сталин. Сталин доказывал, что в виновности врачей нет сомнений, что они убили Жданова, Щербакова, готовились вывести из строя маршалов, умышленно сделали глухим Андреева ${ }^{30}$. Если воспоминания Шепилова, написанные много лет спустя, могли содержать некоторые неточности (сомнительно, в частности, что речь шла о пленуме ЦК, так как мы имеем прямые указания на то, что вопрос рассматривался на Президиуме ЦК), то дневниковые записи Малышева делались по горячим следам. Малышев зафиксировал следующие высказывания Сталина:

«Чем больше у нас успехов, тем больше враги будут нам стараться вредить. Об этом наши люди забыли под влиянием наших больших успехов, появилось благодушие, ротозейство, зазнайство. Любой еврей - националист, это агент американской разведки [...] Среди врачей много евреев-националистов. Неблагополучно в ГПУ. Притупилась бдительность [...]. Надо лечить ГПУ [...]. Надо создать некие формы контроля и проверки. Оживить первичные парторганизации (ячейки) [...]. Прав у них нет, сидят во главе ячеек подхалимы. С этим надо покончить. Надо дать ей право критиковать начальство $[\ldots]$. Отчет областного руководства перед обкомами. Контроль со стороны ЦК за работой МГБ. Лень, разложение глубоко коснулись МГБ» 31 .

Соответствующие положения о борьбе с беспечностью органов госбезопасности и партийном контроле вошли в постановление, оформленное как постановление Президиума ЦК от 4 декабря 1952 г. «О положении в МГБ и о вредительстве в лечебном деле» 32 .

Приведенные Малышевым мысли Сталина, с одной стороны, явно повторяли ряд тезисов, высказанных Сталиным еще на февральско-мартовском пленуме ЦК ВКП(б) в 1937 г., в период развертывания «большого террора», а с другой - подтверждали приверженность Сталина линии, провозглашенной в связи с арестом Абакумова, - усиление партийного контроля над МГБ, чистка чекистских органов с целью активизации их деятельности. В продолжение этой политики в конце декабря 1952 г. Сталин инициировал очередную реорганизацию аппарата МГБ, которая не была реализована лишь в связи с его смертью ${ }^{33}$.

Непосредственным результатом этих усилий Сталина было завершение фабрикации дела «врачей-вредителей» и публичное объявление об этом в январе 1953 г. Проект передовой статьи «Подлые шпионы и убийцы под маской профессоров-врачей», опубликованной в Правде 13 января 1953 г., подвергся существенной собственноручной правке Сталина ${ }^{34}$.

30. Вопросы истории, 7, 1998, с. 32.

31. Источник, 5, 1997, сс. 140-141.

32. Известия ЦК КПСС, 1, 1991, с. 142.

33. А. Кокурин, Н. Петров, «МГБ: структура, функции, кадры», Свободная мыслль, 11, 1997, с. 119.

34. РГАСПИ, ф. 558, оп. 11, д. 157, лл. 9-14. 
Многие историки, как известно, полагают, что намерения Сталина в этот период были более значительными, чем обычная чистка структур МГБ и аресты в среде интеллигенции, что страна стояла накануне новой волны массового террора. Такие предположения не опираются на конкретные документы, но обосновываются рядом более общих соображений. Очевидно, например, что к концу правления Сталина Советский Союз находился в кризисном состоянии, с трудом выдерживал тяготы гонки вооружений и огромных вложений в индустриальные отрасли. Все менее действенной становилась система управления, ориентированная на принуждение и жесткое администрирование. Стране объективно были необходимы перемены. Один из вариантов таких перемен - усмирение общества при помощи массового террора - вполне мог предложить Сталин. Косвенным свидетельством в пользу такой версии служат приведенные в данной статье данные о кадровых чистках в органах госбезопасности. Аресты и перетряски среди чекистов под лозунгом усиления «партийного контроля» в определенной мере напоминали ситуацию 1936-1937 гг., когда Сталин направил в НКВД партийного функционера Ежова и его руками провел «большой террор». В любом случае, периодически повторяя достаточно стандартные и неоднократно опробованные приемы манипулирования органами госбезопасности, Сталин, судя по многим фактам, сохранял контроль над ними, до самой смерти не выпуская из рук этот важнейший рычаг своей диктаторской власти.

Государственный Архив Российской Федерации 119817 МОСКВА

ул. Большая Пироговская 17 